\title{
The Effect of Picture Series in Writing Recount Text in SMPN 1 Malinau Barat
}

\author{
Sepura Cristine \\ Program Studi Pendidikan Bahasa Inggris, Fakultas Keguruan dan Ilmu Pendidikan \\ Universitas Widya Gama Mahakam, Indonesia \\ Jl. KH. Wahid Hasyim No. 28 RT.007 Kota Samarinda, Provinsi Kalimantan Timur \\ sepura0712@gmail.com
}

\begin{abstract}
:
Writing is on important majors that should be mastered by students. However it is hard for students to comprehend a long English passage. The purpose of this study is to investigate the types of activities that occur during the teaching process of writing recount text through a series of pictures and to identify the benefits students receive from writing a recount text through a series of images. The total sampling technique is used in selecting samples. The results of the study revealed that teaching writing using a series of images can improve students' ability to write recount texts. In particular, they show some improvements to the process of writing and vocabulary.
\end{abstract}

Keywords: Writing, Recount Text, Picture Series

\section{Introduction}

In learning English, writing is very important aspect that should be learn by students because given student clear information ideas they learn and given understanding when they are communicating one each other and writing is the basic in learn. By mastering writing, it would be easier for the students to learn English. Therefore, learning how to write has gained considerable importance for last two decades due to two factors: its use as a tool for effective communication of ideas, and the extensive research work carried out in this area to examine various issues faced by L2 writers (Dar \& Khan, 2015; Graham \& Perin, 2007; Haider, 2012; Hyland, 2004).

Writing is combination of process and product. The process refers to the act of gathering ideas and working with them until they are presented in a manner that is polished and comprehensible to readers. The young learners like to know that writing is done in steps which are as important as the steps necessary to cook something such as chicken or eggs, [10]. Another opinion comes from [19], he explains that the writing skills are complex and sometimes difficult to teach, requiring mastery not only of grammatical and rhetorical devices but also of conceptual and judgment elements. It means that writing ability to needs a special skill and process in organizing language material by using learners' own words and ideas and to be a good composition.

In the fact, many English students especially for the eighth grade are often faced with writing problem. It was proved from the pre-research observation done by the researcher to the eight grade students of SMPN 1 Malinau Barat. Based on the research observation, the writer found some students face obstacles in writing. Its indicators are: they have limited of writing, it is hard for them to memorize the meaning of words and their scores of English test are low.

By consider the problems as mentioned above, the writer visited the students in the class to get more information. The writer found some factors that student faced. They are: (1) the students assumed that it's very difficult to get ideas for writing and lack of vocabulary used to write. (2) It's very difficult to start writing because of fear of being wrong or lacking in confidence and wanting the results to be perfect. (3) They were bored with monotonous class atmosphere and activities. From all of problems, it can be conclude that the teachers use teaching techniques are less varied in material transfer. Sometime, the students got less motivate in learning English because the teacher do not use such us appropriate technique in learning process. Both of the teacher and students probably cause this problem. A teacher should have interest way in 
teaching writing to make students fun in learning activities. Here, the writer tries to use series picture for teaching writing in junior high school. The writer would like to try whether it is suitable for the students or not.

\section{Methodology}

The method of this study will be quantitative method. The design of this research is experimental study. The writer use none equivalent Control Group Design. In experimental hypothesis-testing research when a group is exposed to usual condition, it termed a 'control group', but when the group is exposed to some novel or special condition, it is termed an 'experimental group'. It is possible to design studies which include only experimental group or studies which include both experimental and control groups, and then use pre-test post-test or post-test-only [5]. Which a type of this experimental and control group design research is quasi-experimental design with post-test-only design. In a quasi-experimental with post-testonly design, the subjects of the research (two classes) were chosen purposive and the treatment result is introduced into post-test area only [16]. Treatment impact is assessed by subtracting the value of dependent variable between the experimental area and the control area from its value in the test area. The basic assumption in such as a design is that the two areas are identical with respect to their behavior toward the phenomenon considered [7].

\section{Findings and Discussion}

\section{Finding}

The finding of the study is presented to answer the research problems of the study follows:

"Does the use of picture series effect in teaching writing recount text to the eighth grade students of SMPN 1 Malinau Barat in academic Year 2018/2019?"

This study used experimental design, which aimed to find out the use of picture series effect in teaching writing recount text on the eighth grade students of SMPN1 Malinau Barat. The writer had data on writing assessments from both group (experimental group and control group) posttest. Writing assessments uses test indicators were : content, organization, vocabulary, grammar, mechanic. 


\section{The Score of Experimental Group}

Table 1. The Score of the Student Writing Test

\begin{tabular}{|c|c|c|}
\hline Student Number & Students Score & Classification \\
\hline 1 & 84 & Excellent \\
\hline 2 & 60 & Good \\
\hline 3 & 79 & Good \\
\hline 4 & 84 & Excellent \\
\hline 5 & 93 & Excellent \\
\hline 6 & 66 & Good \\
\hline 7 & 60 & Good \\
\hline 8 & 93 & Excellent \\
\hline 9 & 60 & Good \\
\hline 10 & 84 & Excellent \\
\hline 11 & 66 & Good \\
\hline 12 & 79 & Good \\
\hline 13 & 84 & Excellent \\
\hline 14 & 79 & Good \\
\hline 15 & 55 & Fair \\
\hline 16 & 93 & Excellent \\
\hline 17 & 93 & Excellent \\
\hline 18 & 84 & Excellent \\
\hline 19 & 79 & Good \\
\hline 20 & 70 & Good \\
\hline 21 & 70 & Good \\
\hline 22 & 84 & Excellent \\
\hline 23 & 93 & Excellent \\
\hline 24 & 84 & Excellent \\
\hline 25 & 93 & Excellent \\
\hline Total & 1,969 & \\
\hline Mean Score & 78,76 & \\
\hline
\end{tabular}

Based on the Table 1, it could be seen the lowest and the highest score of the experimental class consists of 25 students. In teaching writing recount text, the writer gave the students posttest. The data showed in the post-test that the lowest score was 55 and the highest was 93.

\section{Post Test Experimental Group (VIII-I)}

Table 2. The Score of Controlled Group (VIII-II)

\begin{tabular}{|c|c|c|c|c|c|c|}
\hline \multirow{3}{*}{ No } & \multicolumn{5}{|c|}{ Score } & \multirow{3}{*}{ Total } \\
\hline & Content & organization & Vocabulary & grammar & mechanic & \\
\hline & $13-30$ & $7-20$ & $7-20$ & $5-25$ & $2-5$ & \\
\hline 1 & 26 & 17 & 14 & 22 & 5 & 84 \\
\hline 2 & 21 & 11 & 14 & 9 & 5 & 60 \\
\hline 3 & 25 & 22 & 14 & 13 & 5 & 79 \\
\hline 4 & 26 & 17 & 14 & 22 & 5 & 84 \\
\hline 5 & 30 & 18 & 18 & 22 & 5 & 93 \\
\hline 6 & 21 & 14 & 14 & 12 & 5 & 66 \\
\hline 7 & 21 & 11 & 14 & 9 & 5 & 60 \\
\hline 8 & 30 & 18 & 18 & 22 & 5 & 93 \\
\hline 9 & 21 & 11 & 14 & 9 & 5 & 60 \\
\hline 10 & 26 & 17 & 14 & 22 & 5 & 84 \\
\hline 11 & 21 & 14 & 14 & 12 & 5 & 66 \\
\hline 12 & 25 & 22 & 14 & 13 & 5 & 79 \\
\hline 13 & 26 & 17 & 14 & 22 & 5 & 84 \\
\hline 14 & 25 & 22 & 14 & 13 & 5 & 79 \\
\hline 15 & 16 & 9 & 14 & 12 & 4 & 55 \\
\hline 16 & 30 & 18 & 18 & 22 & 5 & 93 \\
\hline
\end{tabular}




\begin{tabular}{ccccccc}
\hline 17 & 30 & 18 & 18 & 22 & 5 & 93 \\
\hline 18 & 26 & 17 & 14 & 22 & 5 & 84 \\
\hline 19 & 25 & 22 & 14 & 13 & 5 & 79 \\
\hline 20 & 21 & 20 & 11 & 13 & 5 & 70 \\
\hline 21 & 21 & 20 & 11 & 13 & 5 & 70 \\
\hline 22 & 26 & 17 & 14 & 22 & 5 & 84 \\
\hline 23 & 30 & 18 & 18 & 22 & 5 & 93 \\
\hline 24 & 26 & 17 & 14 & 22 & 5 & 84 \\
\hline 25 & 30 & 18 & 18 & 22 & 5 & 93 \\
\hline Total & 625 & 425 & 368 & 427 & 124 & 1.969 \\
\hline Mean & 25 & 17 & 14.72 & 17.08 & 4.96 & 78.52 \\
\hline
\end{tabular}

Table 3. The Score of the Student Writing Test

\begin{tabular}{|c|c|c|}
\hline Student Number & Students Score & classification \\
\hline 1 & 60 & Good \\
\hline 2 & 53 & Good \\
\hline 3 & 43 & Fair \\
\hline 4 & 43 & Fair \\
\hline 5 & 48 & Fair \\
\hline 6 & 43 & Fair \\
\hline 7 & 34 & Less \\
\hline 8 & 34 & Less \\
\hline 9 & 34 & Less \\
\hline 10 & 60 & Good \\
\hline 11 & 43 & Fair \\
\hline 12 & 55 & Fair \\
\hline 13 & 34 & Less \\
\hline 14 & 43 & Fair \\
\hline 15 & 43 & Fair \\
\hline 16 & 55 & Fair \\
\hline 17 & 43 & Fair \\
\hline 18 & 55 & Fair \\
\hline 19 & 34 & Less \\
\hline 20 & 34 & Less \\
\hline 21 & 39 & Less \\
\hline 22 & 43 & Fair \\
\hline 23 & 39 & Less \\
\hline 24 & 60 & Good \\
\hline 25 & 66 & Good \\
\hline Total & 1.138 & \\
\hline Mean Score & 45.52 & \\
\hline
\end{tabular}

Based on the Table 3, it could be seen the lowest and the highest score of the controlled class consists of 25 students. The data showed in the post-test that the lowest score was 34 and the highest was 66.

\section{Post Test Controlled Group (VIII-I)}

Table 4. Scoring Rubric Writing

\begin{tabular}{cccccccc}
\hline \multirow{2}{*}{ No } & \multicolumn{5}{c}{ Score } & \multirow{2}{*}{ Total } \\
\cline { 2 - 6 } & Content & organization & Vocabulary & grammar & mechanic & \\
\cline { 2 - 6 } & $13-30$ & $7-20$ & $7-20$ & $5-25$ & $2-5$ & \\
\hline 1 & 21 & 11 & 14 & 9 & 5 & 60 \\
\hline 2 & 16 & 9 & 14 & 12 & 2 & 53 \\
\hline 3 & 13 & 10 & 12 & 5 & 3 & 43 \\
\hline 4 & 13 & 10 & 12 & 5 & 3 & 43 \\
\hline
\end{tabular}




\begin{tabular}{ccccccc}
\hline 5 & 16 & 7 & 9 & 12 & 4 & 48 \\
\hline 6 & 13 & 10 & 12 & 5 & 3 & 43 \\
\hline 7 & 13 & 7 & 7 & 5 & 2 & 34 \\
\hline 8 & 13 & 7 & 7 & 5 & 2 & 34 \\
\hline 10 & 13 & 7 & 7 & 5 & 2 & 34 \\
\hline 11 & 21 & 11 & 14 & 9 & 5 & 60 \\
\hline 12 & 13 & 10 & 12 & 5 & 3 & 43 \\
\hline 13 & 13 & 9 & 14 & 12 & 4 & 55 \\
\hline 14 & 13 & 7 & 7 & 5 & 2 & 34 \\
\hline 15 & 13 & 10 & 12 & 5 & 3 & 43 \\
\hline 16 & 16 & 9 & 12 & 5 & 3 & 43 \\
\hline 17 & 13 & 10 & 14 & 12 & 4 & 55 \\
\hline 18 & 16 & 9 & 12 & 5 & 3 & 43 \\
\hline 19 & 13 & 7 & 14 & 12 & 4 & 55 \\
\hline 20 & 13 & 7 & 7 & 5 & 2 & 34 \\
\hline 21 & 13 & 9 & 7 & 5 & 2 & 34 \\
\hline 22 & 13 & 10 & 10 & 5 & 2 & 39 \\
\hline 23 & 13 & 9 & 12 & 5 & 3 & 43 \\
\hline 24 & 21 & 11 & 14 & 5 & 2 & 39 \\
\hline 25 & 21 & 14 & 14 & 12 & 5 & 60 \\
\hline Total & 372 & 230 & 11.16 & 7.16 & 5 & 66 \\
\hline Mean & 14.88 & 9.2 & 17 & 78 & 1138 \\
\hline The & 13 & 12 & 45.52 \\
\hline
\end{tabular}

The writer use the statistical method to made computation of the average score (mean) of teaching writing taught without picture series method and teaching writing by using picture series by adding all score and dividing the sum by the number of the students' test, the computation can be seen bellow:

The average score (mean) of control group:

$$
\begin{aligned}
& \bar{X}=\frac{\sum x}{N} \\
& \bar{X}=\frac{1.138}{25} \\
& \bar{X}=45.52
\end{aligned}
$$

The average score (mean) of experimental group:

$$
\begin{aligned}
& \bar{X}=\frac{\sum x}{N} \\
& \bar{X}=\frac{\mathbf{1 . 9 6 9}}{25} \\
& \bar{X}=\mathbf{7 8 . 7 6}
\end{aligned}
$$

The computation above showed the result of mean score of experimental and control group which the control group taught without apply picture series was 45.52 and the experimental group which taught by apply picture series was 78.76. It means that the mean of picture series affect in teaching writing recount text have a good result.

The writer presented the result of the research and that had been obtained from the post-test to know the value t-table.

Table 5. Result of Collecting Writing Test

\begin{tabular}{ccccc}
\hline $\begin{array}{c}\text { Number of } \\
\text { student }\end{array}$ & $\mathbf{X}_{\mathbf{1}}$ & $\mathbf{X}_{2}$ & $\mathbf{X}_{\mathbf{1}^{2}}$ & $\mathbf{X}^{\mathbf{2}^{2}}$ \\
\hline 1 & 84 & 60 & 7056 & 3600 \\
\hline
\end{tabular}




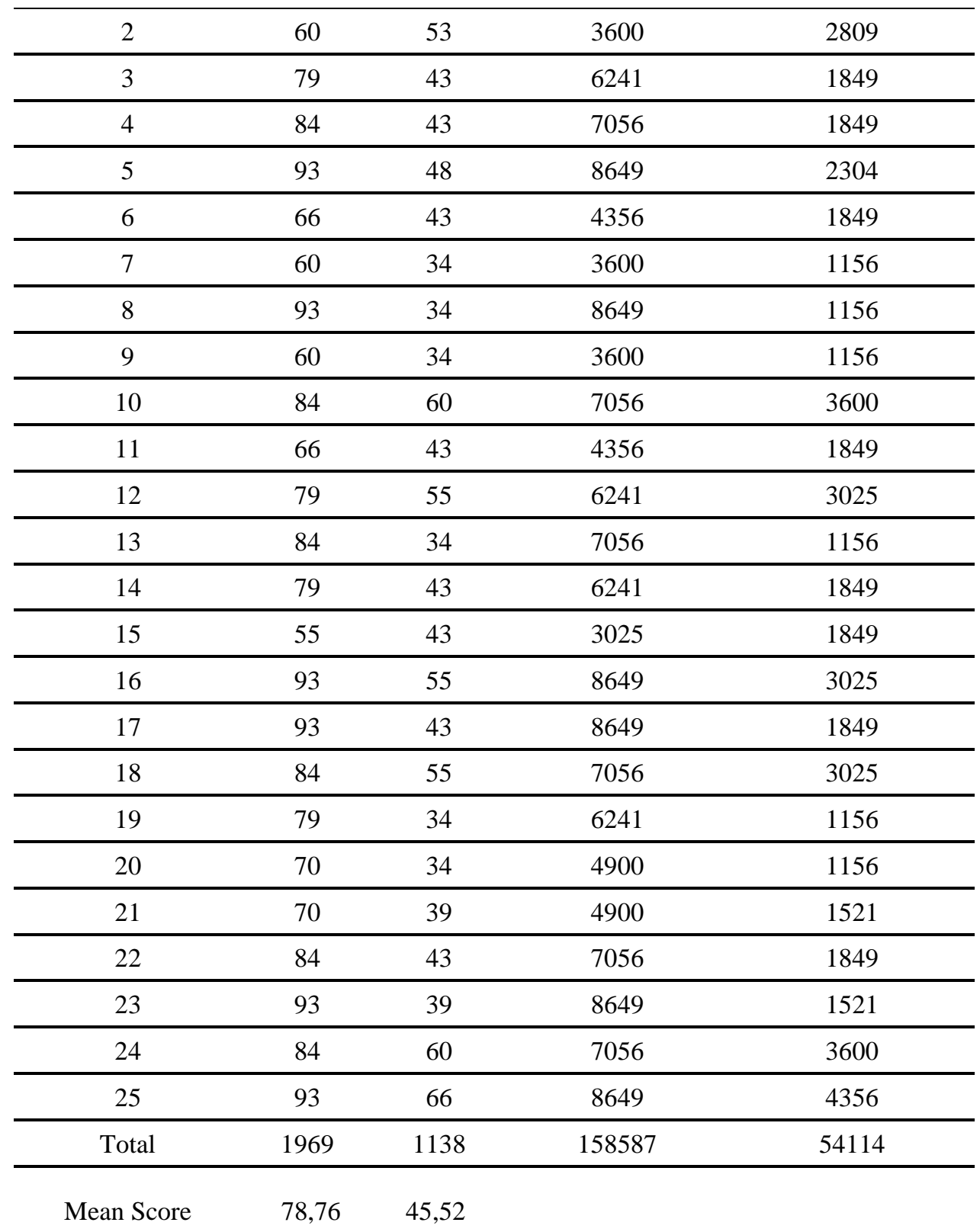

The table above is the result of collecting writing test data from students, the writer analyzed to find a significant difference between the experimental group of students and the control group. The table above shows the data calculation.

\section{Discussion}

Furthermore, the data from observation showed that the students enjoyed in exploring the verbs related to the picture. It can be seen that all students were active and anthusiasm in expressing what they see. They were able to mention the verbs related to kind activities in the pictures. In addition, the students also were able to make the sentences using the verbs. After that, they were able to arrange several the sentence based on the pictures given. This indicates that picture series gives fun learning atmosphere and motivating effect that the students were willing to learn.

In the description of the data which taken from 25 students of experimental class, the writer could explain briefly about the data got from the students before they were analyzed. The description of the experimental class after giving 2 times treatments for experimental class 
using picture series, the writer got the mean of post-test 72.04. The data showed in post-test that the smallest score was 55 and the highest score was 93. Meanwhile, from the description in this class, the writer did not give the students picture series, but the writer only give a theme to writing recount text. After giving 2 times treatments without using picture series, the writer got the mean of post- test 45.52. The data showed in post-test that the smallest score was 34 and the highest score was 60 . It be summarized that the lowest and the highest score in posttest were also higher than pre-test.

In regard with hypothesis statement, it provided that were was significant effect on writing of eight grade students of SMP Negeri 01 Malinau Barat who taught by using picture series.

The finding of the study showed that the treatment of using picture series in writing recount text for 3 meeting had better mean score than without using picture series. Two different treatments were given two different groups of students. Treatment using picture series was given to experimental group and without using picture series was given to the controlled group. After three meeting ended, then the two groups were given a writing test. The test result showed that the significance value of the difference between the mean score of the two groups was higher than the level significance. It means that using picture series gave significant result to the students writing.

\section{Conclusion}

Based on the description of the data analysis on the pervious chapter, the writer Would like to conclude the following result.

1. The result of the student's in writing recount text using picture series and without treatment.

\begin{tabular}{llll}
\hline No & sample & Mean & Different \\
\hline 1 & Experimental Group & 78.76 & \\
\cline { 1 - 3 } 2 & Controlled Group & 45.52 & 33.24 \\
\hline
\end{tabular}

2. The used of picture series affects in writing recount text using and without picture series. Many kinds picture series such as pictures of places, pictures of people in action, pictures from story atc.

3. The weakness of this research was the writer only conducted three times of Treatments in teaching writing recount text by using picture series of SMPN 01 Malinau Barat in academic year 2018/2019.

\section{References}

[1] A. Anderson, and K. Anderson, K, "Text Types in English 2", South Yara: MacMillan Education Australia PTY LTD, 1997.

[2] D. Ary, C.L. Jakobs, C. Sorensen, and A. Razavieh, "Introduction to Research in Education", 2010.

[3] B.Y. Cahyono, and W. Utami, "The Teaching of English as a Foreign Language in Indonesia", Malang: State University of Malang Press, 2011.

[4] Crebert, et, al., "Griffith Graduate Attributes Written Communication Toolkit," Grifith University. International Journal, 2011.

[5] J.W. Creswell, "Educational Research: Planning, Conducting and Evaluating Quantitative and Qualitative Research", Boston: Pearson Education, Inc, 2012.

[6] M.F. Dar and I. Khan, "Writing Anxiety among Public and Private Sectors Pakistani undergraduate university students", Pakistan Journal of Gender Studies, 10(1), 2015. 
[7] L.R. Gay, G.E. Mills, and P. Airasian, "Educational Research: Competencies for Analysis and Applications", Boston: Pearson, 2012.

[8] S. Graham, and D. Perin, "Writing Next-Effective strategies to Improve Writing of Adolescents in Middle and High Schools", The Elementary School Journal, 94(2), 2007.

[9] J. Harmer, "The Practice of English Language Teaching", Assex: Pearson Education, 2001.

[10] J. Harmer, "How to Teach English", England: Longman, 2007.

[11] G. Haider, "An Insight into Difficulties Faced By Pakistani Student Writers: Implications for Teaching of Writing", Journal of Educational and Social Research, 2(3), 2012.

[12] K. Hyland, "Genre and Second Language Writing", The United State of America: The University of Michigan Press, 2004.

[13] W. Hornby, "Dogs, Stars, Rollsroyces and Old Double-decker Buses: Efficiency and Effectiveness in Assessment", 2005.

[14] K. Hyland, "Second Language Writing", 2003.

[15] J. Langan, "Exploring Writing Paragraph and Essay", New Work: McGraw Hill, 2008.

[16] J.H. Mcmillan, and S. Schumacher, "Research in Education: Evidence-BasedInquiry", London: Pearson, 2005.

[17] A. Oshima, and H. Ann, "Introduction to Academic Writing", New York: Pearson Education, 2007.

[18] A. Raimes, and M. Jersky, "Key for writers", USA: Cengange Learning, 2011.

[19] H. Rogers, "Writing Systems: A Linguistic Approach", UK: Blackwell Publishing, 2005.

[20] Y. Rozimela, "The Value of Writing skills in the Senior High School in Indonesia", 2004.

[21] A. Wardiman, "English in Focus", Jakarta: Pusat Pembukuan Departemen Pendidikan Nasional, 2008,

[22] E. Yusnita, S. Clara, and N. Dewi, “Improving Students' Recount Writing Text by Using Picture Series", Pontianak: Tanjungpura University, 2011. 